\title{
LMNA p.R482W mutation related to FPLD2 alters SREBP1-A type lamin interactions in human fibroblasts and adipose stem cells
}

\author{
Brigitte Buendia
}

From 1st French-Italian meeting on laminopathies and other nuclear envelope-related diseases Marseille, France. 15-16 January 2015

SREBP1 (Sterol regulatory element binding protein 1), transcription factor that regulates hundreds of genes involved in lipid metabolism and adipocyte differentiation, is a direct partner of A-type lamins. We show that i) in vitro, the tail regions of prelamin A, lamin A and lamin $C$ bind a polypeptide of SREBP1 and ii) within cells, interactions between wild-type A-type lamins and SREBP1 occur mainly at the nuclear periphery but also within the nucleoplasm. While A-type lamin R482W mutation is responsible for Dunnigan type familial partial lipodystrophy (FPLD2), we show that both overexpression of $L M N A$ p.R $482 \mathrm{~W}$ in primary human preadipocytes and endogenous expression of A-type lamins p.R482W in FPLD2 patient fibroblasts, reduce A-type lamins-SREBP1 in situ interactions and upregulates a large number of SREBP1 target genes [1]. As this LMNA mutant was previously shown to inhibit adipogenic differentiation, we propose that deregulation of SREBP1 by mutated A-type lamins constitutes one underlying mechanism of the physiopathology of FPLD2.

Published: 11 November 2015

\section{Reference}

1. Vadrot N, Duband-Goulet I, Cabet E, Attanda W, Barateau A, Vicart P, et al: The p.R482W substitution in A-type lamins deregulates SREBP1 activity in Dunnigan-type familial partial lipodystrophy. Human molecular genetics 2015, 24(7):2096-109

doi:10.1186/1750-1172-10-S2-013

Cite this article as: Buendia: $L M N A$ p.R482W mutation related to FPLD2 alters SREBP1-A type lamin interactions in human fibroblasts and adipose stem cells. Orphanet Journal of Rare Diseases 2015 10(Suppl 2): 013.

Correspondence: brigitte.buendia@univ-paris-diderot.fr

Unité de Biologie Fonctionnelle et Adaptative (BFA), Université Paris DiderotParis 7, CNRS, UMR 8251, Paris, France

Submit your next manuscript to BioMed Central and take full advantage of:

- Convenient online submission

- Thorough peer review

- No space constraints or color figure charges

- Immediate publication on acceptance

- Inclusion in PubMed, CAS, Scopus and Google Scholar

- Research which is freely available for redistribution
C Biomed Central

\section{Biomed Central}

